\title{
Determination of genistein in rat liver and kidney by a HPLC/UV method. Possible extrapolation from animals to humans
}

\section{Determinarea genisteinei din ficat şi rinichi de şobolan printr-o metoda HPLC/UV. Posibilitatea extrapolarii datelor experimentale la om}

\author{
Amelia Tero-Vescan ${ }^{1}$, Camil-Eugen Vari ${ }^{2 *}$, Daniela-Lucia Muntean ${ }^{3}$, \\ Maria-Titica Dogaru², Cristina Filip ${ }^{1}$, Silvia Imre ${ }^{3}$ \\ 1. Department of Pharmaceutical Biochemistry \\ 2. Department of Pharmacology and Clinical Pharmacy \\ 3. Department of Analytical Chemistry and Drug Analysis \\ University of Medicine and Pharmacy Tirgu Mures
}

\begin{abstract}
A simple and selective method for genistein (GNST) determination in rat liver and kidney was validated in order to study the phytoestrogenic effect of GNST in ovariectomised female Wistar rats. GNST was separated on a Kromasil 100-RP8 column, $150 \mathrm{~mm} \times 4.6 \mathrm{~mm}, 5 \mathrm{~mm}$ equipped with a Kromasil RP 8 precolumn. The mobile phase was 55:45 (v/v) phosphoric acid, $15 \mathrm{mmol}$ in water: methanol at a flow rate of $1.3 \mathrm{ml} / \mathrm{min}$. Luteolin $20 \mu \mathrm{g} / \mathrm{ml} \mathrm{in}$ methanol was used as internal standard (IS). The retention time of GNST was $t_{R}=13.22$ min and $t_{R}=11.60$ min for the IS. Calibration curves in the range 40-400 $\mu \mathrm{g}$ GNST/100g liver and 20-200 $\mu \mathrm{g}$ GNST/100g kidney presented a coefficient of determination higher than 0.99. The method developed presented a good precision and accuracy at the lower limit of quantification LLOQ. 10 white Wistar female rats, 8 weeks of age were treated s.c. with $10 \mathrm{mg}$ GNST/kg bw/day for 8 weeks, while a group of 10 animals were used as controls. The values obtained for GNST in the liver were $192.12 \pm 53.46 \mu \mathrm{g} / 100 \mathrm{~g}$ and $74.51 \pm 12.77 \mu \mathrm{g} / 100 \mathrm{~g}$ in kidney samples.
\end{abstract}

Keywords: genistein, phytoestrogens, HPLC, rat liver, rat kidney.

\section{Rezumat}

A fost validată o metodă simplă şi selectivă de determinare a genisteinei (GNST) din ficat şi rinichi de şobolan $\hat{i n}$ vederea studierii efectului fitoestrogenic al GNST la șobolani Wistar de sex feminin ovariectomizaţi. GNST a fost separată pe o coloană Kromasil 100-RP8, de $150 \mathrm{~mm} x$ 4,6 mm, 5 нm prevăzută cu precoloană Kromasil RP 8 . Faza mobilă a fost 55:45 (v/v) acid fosforic $15 \mathrm{mmol}$ in apă : metanol la un debit de 1,3 $\mathrm{ml} / \mathrm{min}$. Ca standard intern a fost folosită luteolina $20 \mu \mathrm{g} / \mathrm{ml}$ in metanol. Timpul de retenţie al GNST a fost $t_{R}=13,22 \mathrm{~min}_{\text {şi }} t_{R}=11,60 \mathrm{~min}$ pentru standardul intern. Curbele de calibrare pe domeniul 40-400 $\mu \mathrm{g}$ GNST/100g ficat şi 20-200 $\mu \mathrm{g}$ GNST/100g

*Corresponding author: Camil-Eugen Vari, University of Medicine and Pharmacy Tirgu Mures, România, phone: +40-265-21 55 51, e-mail: camil.vari@umftgm.ro 
rinichi au prezentat coeficienţi de determinare $>0,99$. Metoda a prezentat o bună precizie şi acurateţe la limita de cuantificare. 10 şobolani albi Wistar de sex feminin, cu vârsta de 8 săptămâni au fost trataţi s.c. cu $10 \mathrm{mg} / \mathrm{kg}$ c/zi soluţie GNST timp de 8 săptămâni, în timp ce un lot de 10 animale au folosit ca martor. Valorile obţinute pentru GNST în ficat au fost $192.12 \pm 53.46 \mu \mathrm{g} / 100 \mathrm{~g}$, iar în rinichi $74.51 \pm 12.77 \mu \mathrm{g} / 100 \mathrm{~g}$.

Cuvinte cheie: genisteină, fitoestrogeni, HPLC, ficat de șobolan, rinichi de șobolan.

Received: 15 ${ }^{\text {th }}$ October 2013; Accepted: $10^{\text {th }}$ February 2014; Published: $24^{\text {th }}$ February 2014.

\section{Introduction}

Phytoestrogens are naturally occurring compounds, commonly found in plants from Fabaceae family, with low toxicity and remarkable pharmacological properties. Among these compounds the most frequently used is GNST an isoflavonoid with affinity for estrogen receptor beta comparable with estradiol -17 beta (1) with agonist - antagonist activity depending on serum levels of endogenous agonists. GNST is highly active in various organs of the reproductive system such as the vagina, uterus, ovaries or prostate because of the large number of estrogen receptors, and recent studies have shown its role in maintaining blood glucose, body mass, in decreasing triglycerides, LDL-cholesterol and total cholesterol (2).

Another problem that arises is the phytoestrogenic effect in young individuals. A study by Newbold et al (3) show an increase by $31 \%$ of the incidence of cervical cancer in neonatal mice treated subcutaneous with $50 \mathrm{mg} / \mathrm{kg} \mathrm{bw} /$ day for 5 days. Weber et al (4) showed that adult male rats exposed to soy-like isoflavonoids presented decreased serum levels of androgen hormons and a decrease in prostate weight, while in CD-1 immature females mice phytoestrogens accelerated vaginal opening.

Additional deposits of phytoestrogens, and especially GNST, which are found in the liver or kidney can be an important reservoir of estrogen-like substances in postmenopausal women, especially if data obtained on experimental animals can be extrapolated to humans. Isofla- vonoids deposits in various organs and GNST presence in various body fluids has been the subject of numerous laboratory animal studies using $\left[{ }^{14} \mathrm{C}\right]$ radiolabelled GNST (5), HPLC -MS technique (6) or HPLC -DAD (7). These determinations use complex methods of solid phase extraction or liquid-liquid extraction and hydrolysis of glucuronide and sulfo-conjugates by enzymatic systems such as beta-glucuronidase or sulfatase (8).

There is controversy in the literature regarding achieving "steady state" in isoflavonoid level (highly variable oral absorption, rapid elimination from plasma). That is why isoflavones presence in organs as a marker of tissue distribution has to be argued based on pharmacokinetic fundamentals (9).

The purpose of this study was to develop a simple method for extraction and quantification of GNST in rat liver and kidney, organs with a lower number of estrogen receptors that can be a source of phyestrogens after their elimination from plasma. This method was developed as part of a larger study on the effects of GNST in ovariectomised Wistar female rats.

\section{Material and methods}

\section{Analytical method}

Chemicals, reagents, solvents. GNST was purchased from LGC Promochem, Germany and the IS, luteolin, from Fluka. All solvents: ethyl acetate and HPLC grade solvents: methanol and phosphoric acid were bought from Merck (Merck KGaA, Darmstadt, Germany). Purified water 
used was obtained from Millipore SA, Molsheim, France, $\mathrm{NaOH}$ and $\mathrm{HCl}$ were purchased from Merck (Merck KGaA, Darmstadt, Germany).

Preparation of standard solutions, calibration solutions and quality control (QC) samples. Calibration curve was prepared in the range of 40-400 $\mu \mathrm{g}$ GNST/100g liver and 20$200 \mu \mathrm{g}$ GNST/100g kidney by spiking blank liver and kidney samples with GNST and luteolin, as internal standard. A stock solution of $1 \mathrm{mg}$ / $\mathrm{ml} \mathrm{GNST} \mathrm{in} \mathrm{methanol} \mathrm{was} \mathrm{prepared} \mathrm{from} \mathrm{which}$ the following standard solutions were obtained by dilution: 4, 8, 10, 20, 30, 40, $80 \mu \mathrm{g}$ GNST/ $\mathrm{ml}$. Luteolin was used as an IS with a concentration of $20 \mu \mathrm{g} / \mathrm{ml}$ in methanol for the liver samples and $10 \mu \mathrm{g} / \mathrm{ml}$ methanol in kidney samples. QC samples were prepared similarly by spiking blanc liver and kidney samples with GNST standard solutions and were of $20 \mu \mathrm{g}$ GNST \% $\left(\mathrm{QC}_{1}\right)$ and $40 \mu \mathrm{g}$ GNST \% $\left(\mathrm{QC}_{2}\right)$.

Extraction method from organ samples spiked with GNST and IS. $2 \mathrm{~g}$ of rat liver was triturated with a spatula of sand, $100 \mu$ calibration solution $(8,10,20,30,40,80 \mu \mathrm{g} \mathrm{GNST} / \mathrm{ml})$ and $100 \mu \mathrm{IS}(20 \mu \mathrm{g} / \mathrm{ml})$ and was added $5 \mathrm{ml}$ of $10 \%$ $\mathrm{NaOH}$. With the addition of $\mathrm{NaOH}$ fats were saponified. The mixture was stirred for 30 minutes in an ultrasound bath, than it was filtered and the filtrate was added $10 \% \mathrm{HCl}$ to $\mathrm{pH}=3$ for flavone sodium salts hydrolisis. The filtrate was boiled in an oven at $100^{\circ} \mathrm{C}$ for 30 minutes, and after cooling $5 \mathrm{ml}$ of ethyl acetate were added. The organic phase was evaporated to dryness and added $100 \mu 1$ mobile phase and stirred vigurosly. $20 \mu \mathrm{l}$ were injected in the chromatographic system.

In the case of rat kidney samples, one kidney of approximately $1 \mathrm{~g}$ was triturated with a spatula of sand, $100 \mu$ calibration solution $(4,8,10$, $20,30,40 \mu \mathrm{g} \mathrm{GNST} / \mathrm{ml})$ and $100 \mu \mathrm{l}$ IS $(10 \mu \mathrm{g} /$ $\mathrm{ml})$. The extraction method used was the same as in liver samples.

Chromatographic system. Measurements were performed on a Merck Hitachi chromato- graphic system consisting of: L-7100 binary pump with degasser L-7612, L-7200 automatic injector with thermostat L-7360, DAD 455 detector.

Equipment used: AB54S balance (Mettler-Toledo), pH meter MP225 (Mettler-Toledo), centrifuge 2-15 (Sigma), mixer 10 (Falc Instruments), water purification device Direct Q (Millipore), ultrasonic bath Transsonic $\mathrm{T} 700 \mathrm{H}$ (Elma).

Column. Separation was performed on a Kromasil 100-RP8 chromatographic column, $150 \mathrm{~mm} \times 4.6 \mathrm{~mm}, 5 \mu \mathrm{m}$ with Kromasil RP 8 precolumn, at a temperature of $25^{\circ} \mathrm{C}$.

Mobile phase. The analysis was carried out for a period of 20 minutes using a mixture of $55 \%$ mobile phase A - $15 \mathrm{mmol} / 1$ phosphoric acid and methanol with a flow rate of $1.3 \mathrm{ml} /$ min.

Detection was at $259 \mathrm{~nm}$.

\section{Experimental procedures on animals}

Experimental procedures on animals and biological sampling were approved by Ethics Committee of the University of Medicine and Pharmacy Tirgu Mures.

Preparation of GNST solution for s.c. administration. GNST was dissolved in a minimum quantity of dimethyl sulfoxide Merck (Merck KGaA, Darmstadt, Germany), this solution was then diluted with corn oil.

20 white Wistar female rats aged 8 weeks were used. The animals were divided into two groups of 10 animals. Group I was administered s.c. a GNST solution of $10 \mathrm{mg} / \mathrm{kg}$ bw/day for 8 weeks, while the second group served as a control to obtain blank samples of liver and kidney. Animal diet was standardized, controlled without isoflavonoid content.

Extraction method from organ samples obtained from rats treated with GNST. Free GNST and that obtained by hydrolysis according to the procedure described above for calibration samples (saponification of glucuronide and sulfate 
conjugated GNST with $10 \% \mathrm{NaOH}$, followed by acidification with $10 \% \mathrm{HCl}$ ) were quantified in the biological sample.

\section{Results}

\section{Method validation}

1. Specificity of the method. 6 blank rat liver and kidney samples were extracted individual- ly and injected (Figure 1 and Figure 2). At the retention time of GNST (13.22 $\mathrm{min}$ ) and of IS (11.60 $\mathrm{min})$ interferences are not observed in blank liver or kidney extract.

2. Linearity domanin and LLOQ. Chromatograms of a rat liver and kidney sample at the lower limit of quantification LLOQ, spiked with 40 $\mu \mathrm{g} / 100 \mathrm{~g}$ GNST $\left(\mathrm{t}_{\mathrm{R}}=13.22 \mathrm{~min}\right)$ and $100 \mu \mathrm{g} / 100 \mathrm{~g}$

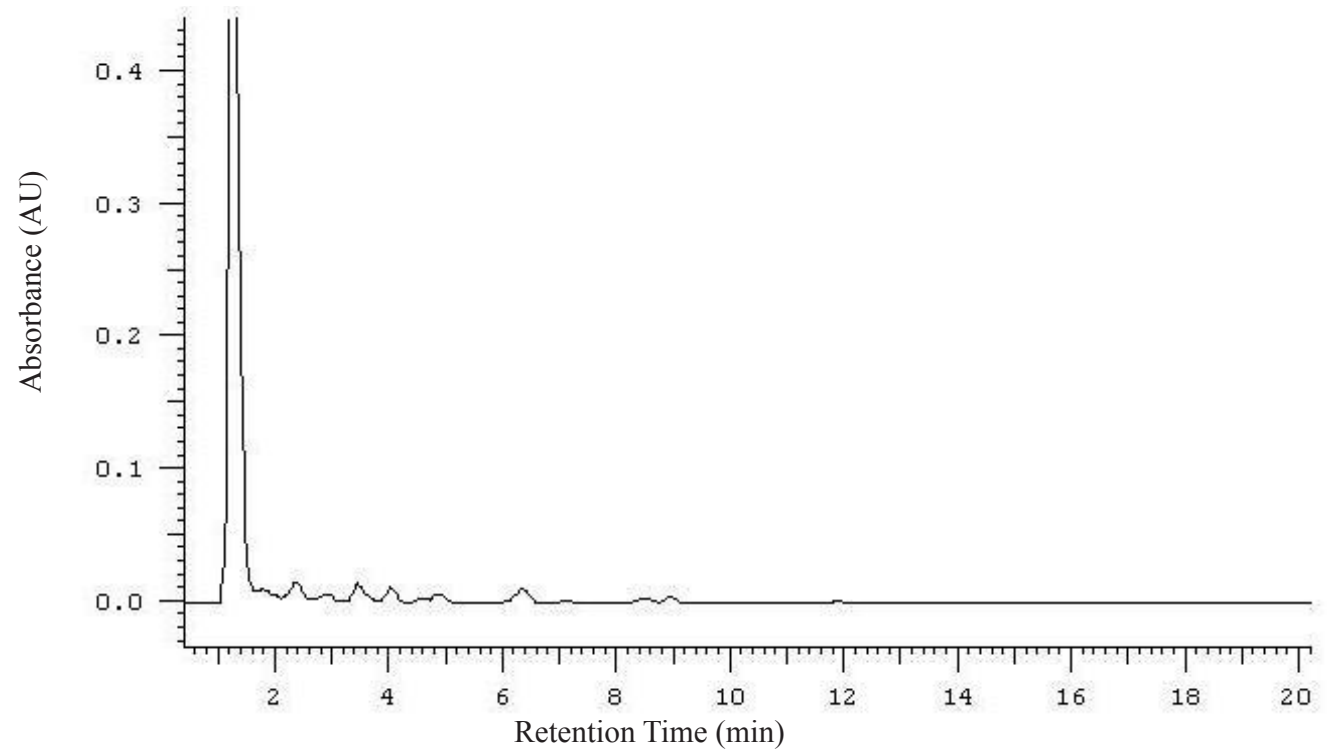

Figure 1. Chromatogram of a blank liver extractive solution

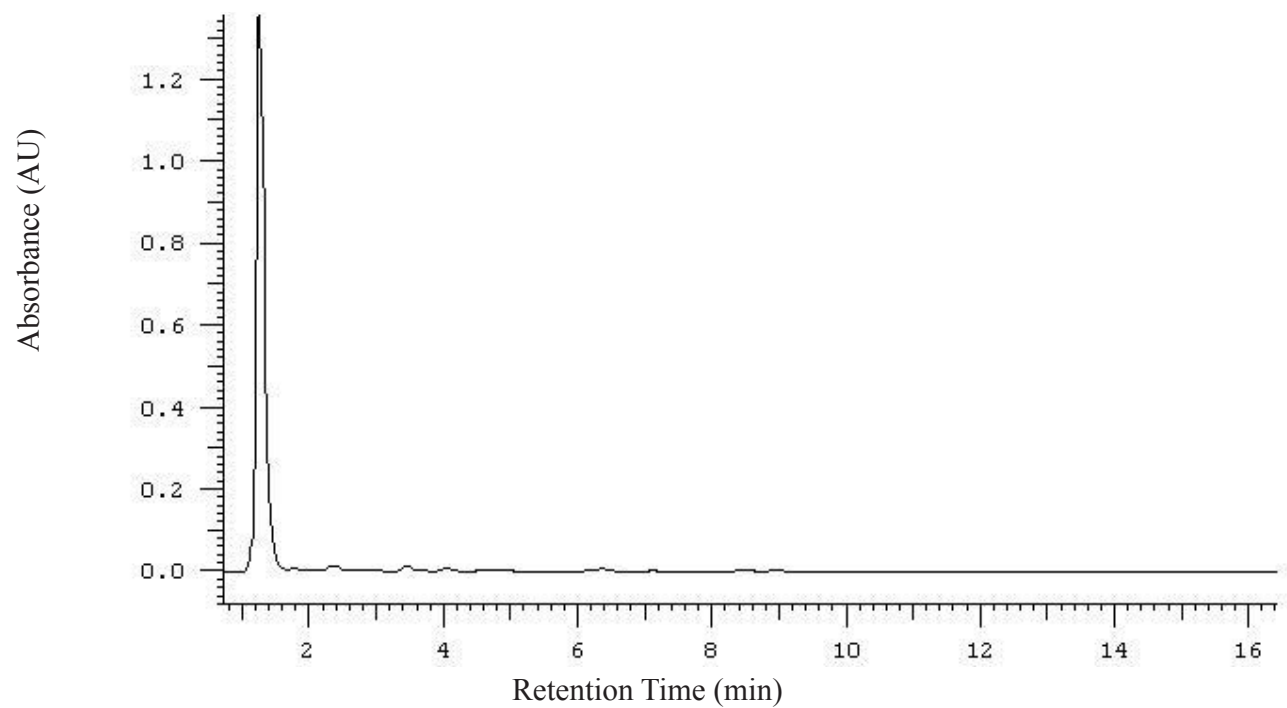

Figure 2. Chromatogram of blank kidney extractive solution 
IS $\left(\mathrm{t}_{\mathrm{R}}=11.60 \mathrm{~min}\right)$ in the case of liver, and $20 \mu \mathrm{g} / 100 \mathrm{~g}$ GNST and $50 \mu \mathrm{g} / 100 \mathrm{~g}$ IS for kidney sample are shown in Figure 3 and Figure 4. LLOQ was set at the lowest concentration standard (40 $\mu \mathrm{g}$ GNST/100g liver and $20 \mu \mathrm{g}$ GN$\mathrm{ST} / 100 \mathrm{~g}$ kidney) with an accuracy and precision of less than $20 \%$.

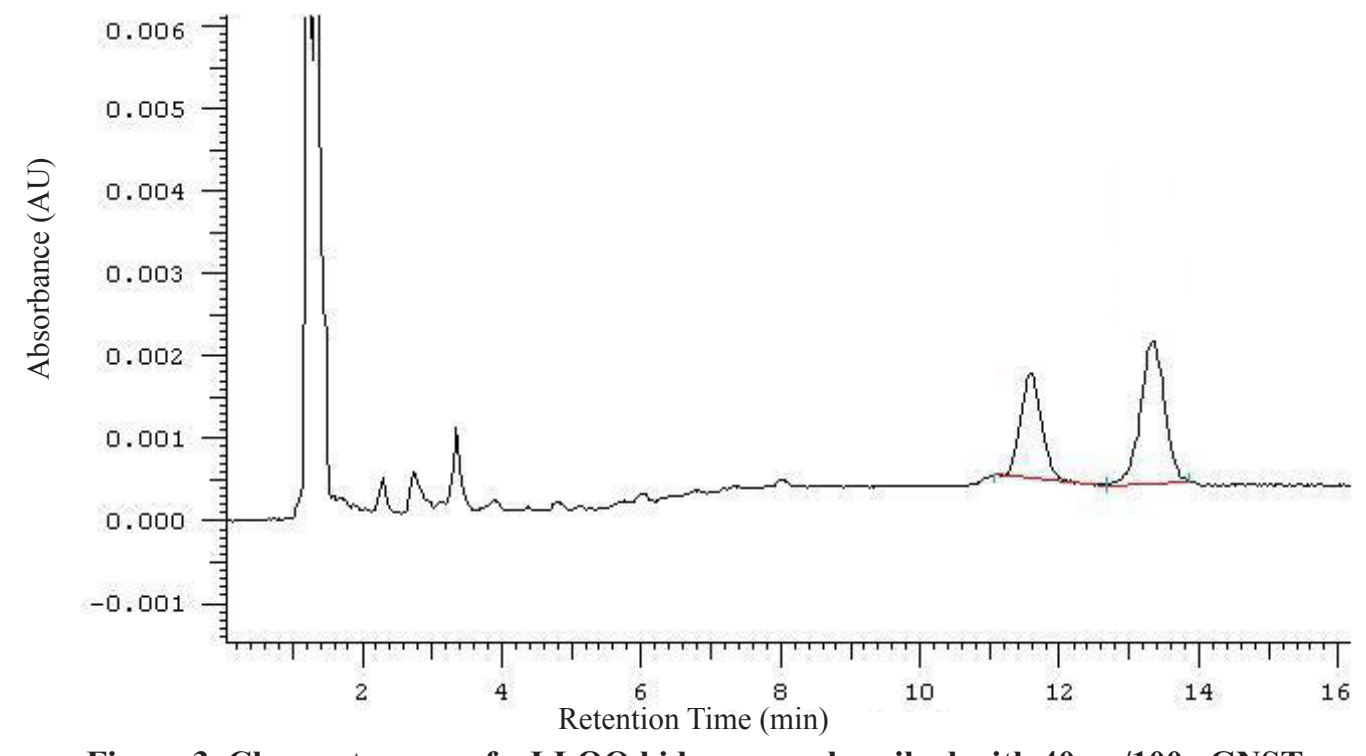

Figure 3. Chromatogram of a LLOQ kidney sample spiked with $40 \mu \mathrm{g} / 100 \mathrm{~g}$ GNST $(\mathrm{tR}=13.22 \mathrm{~min})$ and $100 \mu \mathrm{g} / 100 \mathrm{~g}$ IS $(\mathrm{tR}=11.60 \mathrm{~min})$

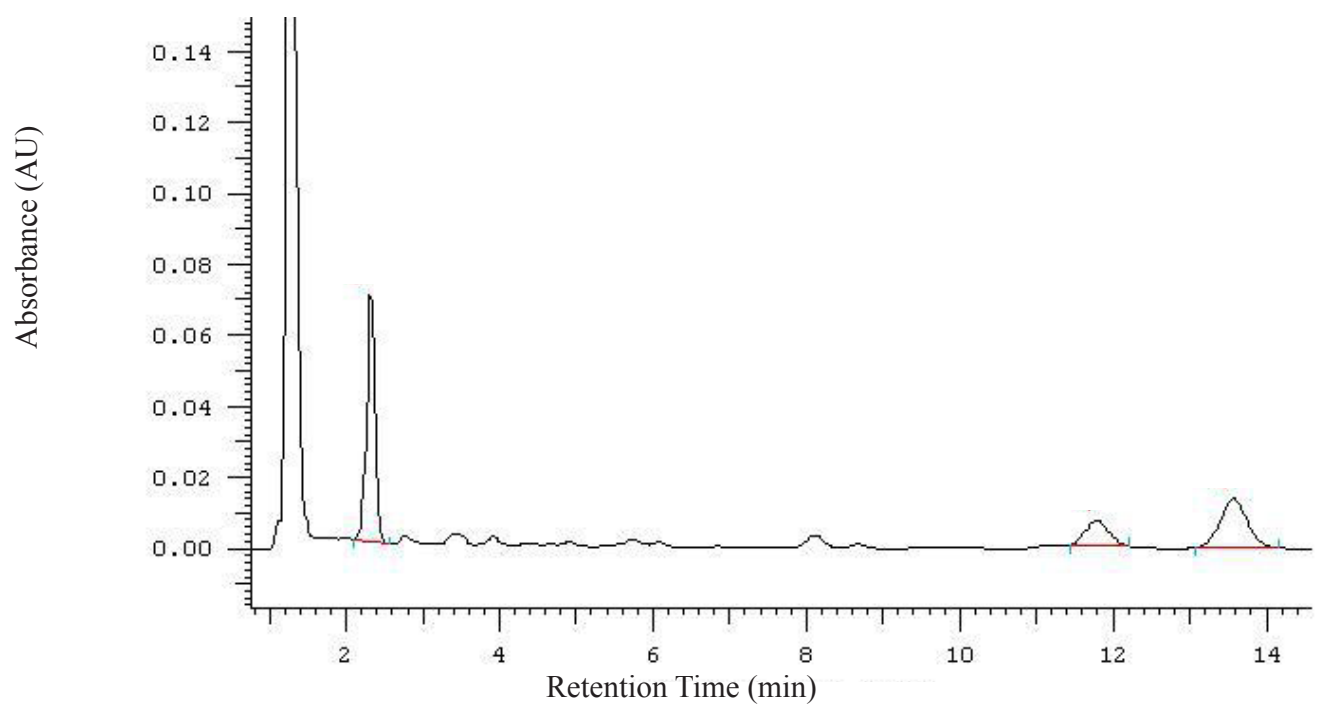

Figure 4. Chromatogram of a LLOQ liver sample spiked with $20 \mu \mathrm{g} / 100 \mathrm{~g}$ GNST $(\mathrm{tR}=13.22 \mathrm{~min})$ and $50 \mu \mathrm{g} / 100 \mathrm{~g}$ IS (tR $=11.60 \mathrm{~min})$ 
Table I. Precision, accuracy and recovery within series $(n=5)$.

\begin{tabular}{|c|c|c|c|c|c|c|}
\hline Matrix & & $\begin{array}{c}\mathbf{c}_{\text {nominal }} \\
(\mu \mathrm{g} / 100 \mathrm{~g} \\
\text { biological } \\
\text { product })\end{array}$ & $\begin{array}{c}\text { Mean } c_{\text {found }} \\
(\mu \mathrm{g} / 100 \mathrm{~g} \\
\text { biological } \\
\text { product })( \pm \mathrm{SD})\end{array}$ & Recovery\% ( \pm SD $)$ & $\begin{array}{c}\text { Precision } \\
\text { (CV\%) }\end{array}$ & Bias \% \\
\hline \multirow[t]{3}{*}{ liver } & IS & 100 & $72.91( \pm 6.88)$ & $72.91( \pm 6.88)$ & 9.44 & -27.09 \\
\hline & GNST & 20 & $15.16( \pm 1.49)$ & $75.80( \pm 7.49)$ & 9.89 & -24.20 \\
\hline & & 40 & $31.63( \pm 2.71)$ & $79.08( \pm 6.77)$ & 8.57 & -20.91 \\
\hline \multirow[t]{3}{*}{ kidney } & IS & 50 & $38.25( \pm 2.10)$ & $71.77( \pm 5.15)$ & 5.50 & -28.23 \\
\hline & GNST & 20 & $14.70( \pm 1.98)$ & $73.51( \pm 9.91)$ & 13.48 & -26.49 \\
\hline & & 40 & $28.64( \pm 2.07)$ & $71.61( \pm 5.18)$ & 7.24 & -28.39 \\
\hline
\end{tabular}

Table II. Precision, accuracy and recovery between series $(n=5)$.

\begin{tabular}{|c|c|c|c|c|c|c|}
\hline Matrix & & $\begin{array}{c}c_{\text {nominal }} \\
(\mu g / 100 g \\
\text { biological } \\
\text { product })\end{array}$ & $\begin{array}{c}\text { Mean }_{\text {found }} \\
(\mu \mathrm{g} / \mathbf{1 0 0 g} \\
\text { biological } \\
\text { product })( \pm \mathrm{SD})\end{array}$ & Recovery\% $( \pm$ SD) & $\begin{array}{c}\text { Precision } \\
\text { (CV\%) }\end{array}$ & Bias \% \\
\hline \multirow[t]{3}{*}{ liver } & IS & 100 & $79.43( \pm 5.09)$ & $79.43( \pm 5.09)$ & 6.41 & -20.57 \\
\hline & \multirow[t]{2}{*}{ GNST } & 20 & $16.24( \pm 1.58)$ & $81.20( \pm 7.93)$ & 9.77 & -18.80 \\
\hline & & 40 & $34.98( \pm 2.99)$ & $87.46( \pm 7.48)$ & 8.56 & -12.54 \\
\hline \multirow[t]{3}{*}{ kidney } & IS & 50 & $38.17( \pm 3.30)$ & $76.35( \pm 8.10)$ & 8.66 & -23.65 \\
\hline & \multirow[t]{2}{*}{ GNST } & 20 & $14.50( \pm 2.05)$ & $72.50( \pm 10.25)$ & 14.13 & -27.50 \\
\hline & & 40 & $30.98( \pm 3.60)$ & $77.46( \pm 9.02)$ & 11.69 & -22.54 \\
\hline
\end{tabular}

for liver and $\mathrm{y}=56.32( \pm 13.54) \mathrm{x}-7.43( \pm 6.56)$ with 6 points and 5 calibration measurements for each point. The residual distribution was within the limits of $\pm 11 \%$.

4. Precision, accuracy, recovery. Accuracy and precision of the method was determined using QC samples (Table I and Table II). Precision expressed by $\mathrm{CV} \%$ and accuracy expressed by relative error (bias\%) was calculated for 5 samples injected in the same day and on different days at both levels of concentration $\mathrm{QC}_{1}$ and $\mathrm{QC}_{2}$. The concentration values for $\mathrm{QC}$ samples were chosen according to the liver and kidney GNST values that other studies have reported after GNST administration by subcutaneous injection in rats. (9). The average recovery was over $70 \%$ for the liver and kidney samples.
Table III. Rat liver and kidney values of GNST

\begin{tabular}{ccc}
\hline sample & $\begin{array}{c}\mathbf{C}_{\text {GNST }} \\
(\boldsymbol{\mu g} / \mathbf{1 0 0 g} \text { liver })\end{array}$ & $\begin{array}{c}\mathbf{C}_{\text {GNST }} \\
(\boldsymbol{\mu g} / \mathbf{1 0 0 g} \text { kidney })\end{array}$ \\
\hline 1 & 233.75 & 67.45 \\
\hline 2 & 267.25 & 55.67 \\
\hline 3 & 195.39 & 74.23 \\
\hline 4 & 61.38 & 66.55 \\
\hline 5 & 144.87 & 102.44 \\
\hline 6 & 227.23 & 80.56 \\
\hline 7 & 207.56 & 65.88 \\
\hline 8 & 167.55 & 70.23 \\
\hline 9 & 190.67 & 82.74 \\
\hline 10 & 225.56 & 79.43 \\
\hline average & 192.12 & 74.51 \\
\hline SD & 53.46 & 12.77 \\
\hline CV\% & 27.82 & 17.14 \\
\hline
\end{tabular}


5. Stability studies. GNST stability in biological samples was tested on QC samples injected and concentration calculated from the calibration curve of the day in the rat plasma samples at room temperature, after three repeated cycles of freezing and thawing $(10,11)$.

\section{Analysis of biological samples}

Liver and kidney samples chromatograms of GNST treated group are shown in Figure 5 and Figure 6. GNST values are $192.12 \pm 53.46$ $\mu \mathrm{g} / 100 \mathrm{~g}$ in liver and $74.51 \pm 12.77 \mu \mathrm{g} / 100 \mathrm{~g}$ in kidney (Table III). GNST values in the liver is

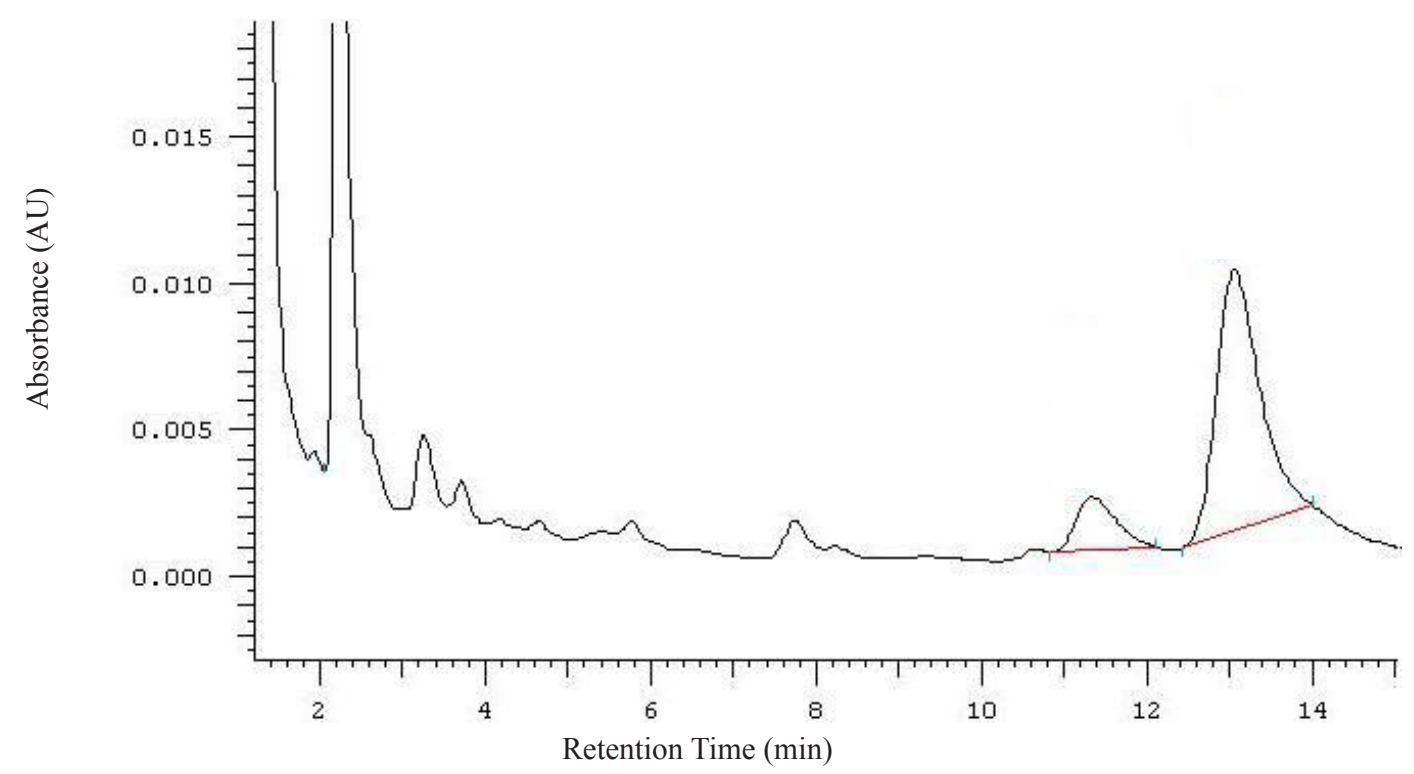

Figure 5. Chromatogram of a rat liver sample

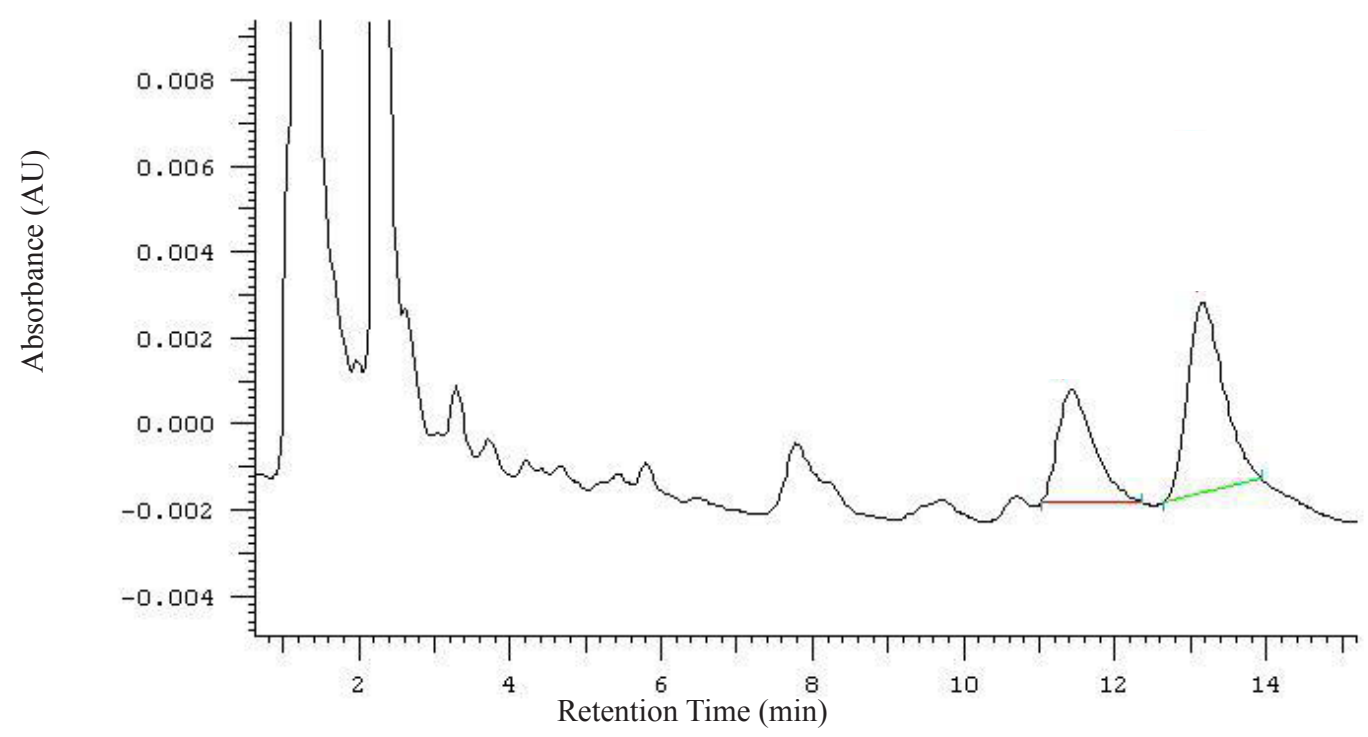

Figure 6. Chromatogram of a rat kidney sample 
double than in kidney but interindividual variability of results is also much higher.

\section{Discussion}

Clinical trials of medicinal products must be preceded by non-clinical studies (including pharmacokinetic ones) even if their extrapolation to humans is not conclusive $(12,13)$. All official monographs of drugs (Summary of Product Characteristics) validated by the regulatory authorities (Romanian National Agency of Medicine, EMEA, FDA) should include preclinical safety data. Organ distribution studies in humans raise ethical issues or require administration of radiolabeled compounds that are not hazardous to health and life. Therefore, animal studies are used as a guide for predicting drug behavior in humans. In case of food supplements, legislation is more permissive (14). Most dietary supplements on the market do not have clinical or non-clinical efficacy data (their use is based solely on the alleged lack of toxicity and longtime empirical use).

Hepatic metabolism of genistein varies, with species specific. While in rats where unmetabolised GNST represents less than $10 \%$ of the total GNST, in humans the proportion of unchanged substance is highly variable (from 0 to $58.3 \%$ ). Comparative studies on cryopreserved hepatocytes showed that the main metabolite of GNST, both in humans and in rats is 4' -O- glucuronide-GNST (15). Other compounds obtained in the phase II metabolic reactions (4' -O- sulfate genistein -7 - O- glucuronide, GNST 4' -O- glucuronide, or GNST-7-O-sulfate and GNST-4'O-sulfate) are quantitatively unimportant. The lack of primary metabolites obtained by phase I metabolic reaction-3', 6, 8 aromatic hydroxylation (although their appearance is predictable by in silico studies (15)), by means of isoforms $\mathrm{CYP}_{1} \mathrm{~A}_{2}, \mathrm{CYP}_{2} \mathrm{C}_{9}, \mathrm{CYP}_{2} \mathrm{C}_{19}, \mathrm{CYP}_{3} \mathrm{~A}_{4}$ is caused by minor importance of this metabolic pathway and the enzyme inhibitory activity of GNST on $\mathrm{CYP}_{450}$ isoforms described by Moon et al (16).

In rats, distribution and storage of genistein in the organs is age dependent, young rats have $75 \%$ higher levels of GNST in the liver than in skeletal muscle, in older animals, the storage capacity of the liver decreases (9). Although all literature studies show a short half-life of GNST (being totally eliminated from the blood after 12 hours, unable to speak of a true steady state) (9), a part of GNST is not renally excreted and is stored in tissues and organs. Distribution of GNST and metabolites in different organs is uneven, as a result of local blood flow and differences in UDP-glucuronyltransferases activity.

Considering the short half-life of GNST as parental drug, the compound was administered parenterally as oily solution. This administration pathway was necessary to get a saturation level in targeted organs by the developed method. This saturation level is in equilibrium with a cvasistationary plasma concentration of GNST.

Our results show higher levels of total GNST (unmetabolised or obtained by hydrolysis of conjugated metabolites) in liver than in kidney. These differences may be explained by the fact that the kidney serves as an elimination organ of the conjugated compound while at hepatic level the bile elimination of glucuronides may be followed by re-absorption of the compound obtained by enzymatic hydrolysis in the duodenum (enterohepatic circulation). Our study presents that despite the apparent short half-life of GNST, some organs serve as storage for GNST in case of a regular intake of the substance.

The method developed is rapid, sensitive, reproducible, does not require laborious sample processing and can serve to quantify izoflavonoides in tissue for pharmacokinetic studies, isolation and identification of metabolites and to reflect storage capacity of various organs. 


\section{References}

1. McCarty MF. Isoflavones made simple. Genistein's agonist activity for the beta-type estrogen receptor mediates their health benefits. Med Hypotheses. 2006;66(6):1093-114. DOI: 10.1016/j. mehy.2004.11.046

2. Cederroth CR, Nef S. Soy, phytoestrogens and metabolism: A review. Molecular and Cellular Endocrinology. 2009 May 25;304(1-2):30-42. DOI: 10.1016/j. mce.2009.02.027

3. Newbold RR, Banks EP, Bullock B, Jefferson WN. Uterine adenocarcinoma in mice treated neonatally with genistein. Cancer Res. 2001 Jun 1;61(11):4325-8.

4. Weber KS, Setchell KD, Stocco DM, Lephart ED. Dietary soy-phytoestrogens decrease testosterone levels and prostate weight without altering LH, prostate 5alpha-reductase or testicular steroidogenic acute regulatory peptide levels in adult male Sprague-Dawley rats. J Endocrinol. 2001 Sep;170(3):591-9. DOI: 10.1677/ joe. 0.1700591

5. Coldham NG, Sauer MJ. Pharmacokinetics of [14C] genistein in the rat: gender-related differences, potential mechanisms of biological action and implications for human health. Toxicol Appl Pharmacol. 2000;164(2):206-15. DOI: 10.1006/taap.2000.8902

6. Grace PB, Mistry NS, Carter MH, Leath AJ, Teale P. High throughput quantification of phytoestrogens in human urine and serum using liquid chromatography / tandem mass spectrometry (LC-MS/MS). J Chromatogr B. 2007;853(1-2):138-46. DOI: 10.1016/j. jchromb.2007.03.011

7. Tamames-Tabara C, Imbuluzqueta E, Campanero MA, Horcajada P, Blanco-Prietoa MJ. A simple and robust high-performance liquid chromatography coupled to a diode-array detector method for the analysis of genistein in mouse tissues. J Chromatogr B. 2013;935:47-53. DOI: 10.1016/j.jchromb.2013.07.020

8. Matthies A, Loh G, Blaut M, Braune A. Daidzein and Genistein Are Converted to Equol and 5-Hydroxy-Equol by Human Intestinal Slackia isoflavoniconvertens in Gnotobiotic Rats. J Nutr. 2012 Jan 1;142(1):40-6. DOI: 10.3945/jn.111.148247

9. Chen C-Y, Bakhiet RM. Age decreased steady-state concentrations of genistein in plasma, liver, and skeletal muscle in Sprague-Dawley rats. Mech Ageing Dev. 2006 Apr;127(4):344-8. DOI: 10.1016/j. mad.2005.12.003

10. Joshi JV, Vaidya RA, Pandey SN, Agashe S, Chandrasekharan S, Menon SK, et al. Plasma levels of genistein following a single dose of soy extract capsule in Indian women. Indian J Med Res. 2007 Apr;125(4):534-41.

11. Tero-Vescan A, Imre S, Vari CE, Dogaru MT. Determination of genistein in plasma by HPLC-UV. Timisoara Medical Journal. 2008;58(Supplement 2):10-4

12. *** International Conference on Harmonisation of Technical Requirements for Registration of Pharmaceuticals for human use, Guidance on nonclinical safety studies for the conduct of human clinical trials and marketing authorization for pharmaceuticals, ICH Harmonised Tripartite Guideline M3(R2), 2009

13. *** ICH Common Technical Document (CTD), vol 2B - Notice to Applicants, Medicinal products for Human use (http://ec.europa.eu/health/files/eudralex/vol-2/b/ update_200805/ctd_05-2008_en.pdf)

14. **** ,Order no. $24 \overline{4} / 401 / 2005$ of the Minister of Agriculture, Forestry and Rural Development and the Minister of Health of Romania"

15. Bursztyka J, Perdu E, Tulliez J, Debrauwer L, Delous $\mathrm{G}$, Canlet $\mathrm{C}$, et al. Comparison of genistein metabolism in rats and humans using liver microsomes and hepatocytes. Food and Chemical Toxicology. 2008 Mar;46(3):939-48. DOI: 10.1016/j.fct.2007.10.023

16. Moon YJ, Wang X, Morris ME. Dietary flavonoids: Effects on xenobiotic and carcinogen metabolism. Toxicology in Vitro. 2006 Mar;20(2):187-210. DOI: 10.1016/j.tiv.2005.06.048 